OmniAkuatika, 11 (2): 6-14, 2015
ISSN: 1858-3873 print / 2476-9347 online
Research Article

\title{
EVALUASI KEGIATAN AKUAKULTUR DI KOLONG PASCA TAMBANG : ANALISIS PENCEMARAN AIR KOLONG
}

\section{Eva Prasetiyono}

\begin{abstract}
Jurusan Budidaya Perairan, Fakultas Pertanian Perikanan dan Biologi, Universitas Bangka Belitung, Kampus Terpadu Universitas Bangka Belitung, Desa Balunijuk, Kecamatan Merawang, Kabupaten Bangka, Provinsi Kep. Bangka Beltung 33172.
\end{abstract}

*Corresponding author: evaintegral@gmail.com

\begin{abstract}
Ex-tin mining lakes are commonly used by many people in Bangka Island for fish farming activities. The water logs of post mining lakes have been used for fish farming activities. We hypothesized possibly environmental pollution related to the water quality. This paper aimed to evaluate fish farming activities by the local communities using the waterlogs of post mining lakes. The evaluation was based on heavy metals extent in the water using survey method with purposive sampling in order to determine which extin mining lakes would be feasible for aquaculture activities. The data of the content of heavy metals and water qualities were analyzed using the method of Pollution Index (PI). According to the age of mining lakes, the five ex-tin mining lakes which has been observed. The results showed one new aged, two middle aged, and one old age; meets the quality standard eligibility for fish farming activities, while the middle aged was low polluted. The age of ex-tin mining lakes not affected nor the extent of the pollution levels or water qualities.
\end{abstract}

Keywords : ex-tin mining, lakes, aquaculture, water qualities, pollution index, fish

\section{PENDAHULUAN}

Kolong pasca tambang banyak tersebar di daerah Kepulauan Bangka Belitung. Kolongkolong ini terbentuk dari hasil kegiatan penambangan timah baik yang dilakukan oleh pemerintah, swasta maupun masyarakat umum. Jumlah kolong saat ini terus meningkat karena kegiatan penambangan timah yang masih terus berlangsung. Bahkan diperkirakan lebih dari 1000 kolong telah terbentuk baik di pulau Bangka maupun Pulau Belitung.

Kolong secara umum terdiri atas kolong muda, kolong menengah dan kolong tua. Pembagian kolong ini didasarkan pada usia kolong. Kolong muda merupakan kolong yang baru terbentuk dengan usia yang kurang dari 5 tahun. Karakteristik utama dari kolong muda yaitu kandungan logam berat di air tinggi dan $\mathrm{pH}$ airnya rendah (2-4). Kolong menengah atau kolong sedang memiliki usia antara $5-20$ tahun dengan karakteristik logam di air masih cukup tinggi dan $\mathrm{pH}$ antara $4-6$. Kolong tua merupakan kolong yang kondisi biogeofisik yang sudah normal dan memiliki pH antara 5,5 - 7 dengan kandungan logam berat di kolom air yang rendah (Henny dan Susanti, 2009; Pupita et al, 2006).

Banyak masyarakat yang memanfaatkan kolong untuk kebutuhan sehari-hari. Kolong dimanfaatkan sebagai sumber air baku bagi masyarakat untuk minum dan keperluan rumah tangga. Kolong juga banyak dimanfaatkan masyarakat untuk mengairi tanaman pertanian, peternakan dan media kegiatan budidaya Ikan.

Kegiatan Budidaya ikan dengan memanfaatkan kolong pasca tambang telah banyak dilakukan oleh masyarakat. Kolong yang dimanfaatkan oleh masyarakat adalah kolong yang kualitas airnya mampu menunjang kelangsungan hidup dan pertumbuhan ikan. Sistem budidaya ikan yang banyak dilakukan yaitu water base aquaculture dengan menggunakan keramba jaring/waring apung (KJA) atau keramba jaring/waring tancap (KJT) sedangkan land base aquaculture dengan menggunakan kolam terpal, kolam tanah atau kolam semen penerapannya lebih sedikit.

Secara prinsip penggunaan kolong untuk kegiatan budidaya ikan (akuakultur) dapat dilakukan bila kualitas airnya memenuhi persyaratan hidup bagi organisme budidaya. Sumber-sumber air yang kualitas airnya tidak memenuhi parameter fisika, kimia dan biologi tidak dapat digunakan untuk budidaya karena akan menghambat pertumbuhan ataupun mematikan organisme budidaya (Kordi dan Tancung 2007). Selain itu, salah satu parameter kimia air berupa logam berat menjadi parameter yang sangat penting diperhatikan. Hal ini 
dikarenakan bila air sebagai media budidaya mengandung logam berat maka logam berat tersebut dimungkinkan dapat intrusi kedalam tubuh ikan dan terakumulasi sehingga berbahaya jika dikonsumsi manusia (Prasetiyono, 2013).

Kolong yang berumur tua sering digunakan untuk budidaya ikan karena kualitas airnya terutama nilai $\mathrm{pH}$ air telah memenuhi persyaratan hidup bagi ikan budidaya. Selain itu kandungan logam berat pada kolom air di kolong tua juga rendah. Namun walaupun demikian kandungan logam berat di sedimen sangat tinggi. Proses biomagnifikasi memungkinkan logam berat dapat terakumulasi didalam tubuh ikan. Logam berat timah hitam $(\mathrm{Pb})$, seng $(\mathrm{Zn})$ dan tembaga $(\mathrm{Cu})$ adalah logam berat yang keberadaannya di kolong cukup tinggi (Henny 2010).

Berdasarkan pengamatan lapangan ternyata kegiatan budidaya ikan oleh masyarakat tidak hanya dilakukan di kolong-kolong yang berusia tua. Kolong-kolong yang berusia muda ataupun menengah banyak yang dimanfaatkan untuk kegiatan budidaya. Hal ini terutama dilakukan pada kolong-kolong muda dan menengah yang dangkal (kedalaman kurang dari meter). Kolong-kolong ini merupakan kolongkolong yang telah mengalami proses pulih alami (self purification) lebih cepat dan memiliki nilai $\mathrm{pH}$ air sesuai dengan kehidupan ikan-ikan budidaya. Namun hal ini perlu dilakukan penelitian karena dikhawatirkan ketercemaran perairan oleh limbah organik sisa pakan dari kegiatan budidaya ikan dan kandungan logam berat di kolom perairan masih cukup tinggi yang menyebabkan perairan kolong tidak layak digunakan untuk aktivitas budidaya.

\section{BAHAN DAN METODE}

\section{Waktu dan Tempat}

Penelitian ini dilaksanakan pada bulan Juni 2014. Kolong yang digunakan yaitu kolongkolong yang berada di Kabupaten Bangka dan Kabupaten Bangka Tengah. Analisis kandungan logam berat $\mathrm{Pb}, \mathrm{Zn}$ dan $\mathrm{Cu}$ dilakukan $\mathrm{di}$ Laboratorium Teknologi Industri Pertanian (TIN) IPB. Analisis kualitas air dilakukan di Laboratorium MIPA Universitas Bangka Belitung (UBB)

\section{Alat dan Bahan}

Alat-alat yang digunakan dalam penelitian ini antara lain : botol sampel, automatic sampler, AAS (Atomic Absorption Spectrophotometer), Spektrofotometer UVVis, $\mathrm{pH}$ meter, DO meter dan peralatan titrasi, gelas kimia, gelas ukur, gelas BOD, inkubator, pipet volumetrik, labu ukur, tabung erlenmeyer, timbangan digital, magnetic stirrer, microwave, termometer. Bahanbahan yang digunakan yaitu ikan-ikan budidaya, akuades, larutan pereaksi dan larutan standar untuk pengukuran kualitas air.

\section{Parameter Pengamatan}

Kandungan logam berat di air dan daging ikan

Kandungan logam berat yang dianalisis yaitu $\mathrm{Pb}, \mathrm{Zn}$, dan $\mathrm{Cu}$. Analisa logam berat dilakukan dengan menggunakan spektrofotometer serapan atom (Atomic Absorption Spectrophotometer). AAS merupakan prosedur spectroanalytical untuk penentuan kualitatif dan kuantitatif dari unsur-unsur kimia menggunakan penyerapan radiasi optik (cahaya) oleh atom bebas dalam bentuk gas. Tujuan penggunaan AAS untuk analisis logam berat yaitu menentukan kadar suatu unsur logam dari campurannya berdasarkan serapan atomnya. Uji kandungan logam berat pada daging ikan dilakukan dengan terlebih dahulu melakukan preparasi sampel daging ikan dengan cara destruksi basah menggunakan microwave.

\section{Parameter fisika dan kimia air}

Parameter fisika dan kimia air yang dianalisis yaitu suhu, kekeruhan, kecerahan, $\mathrm{pH}$, Dissolved Oxygen (DO), nitrat $\left(\mathrm{NO}_{3}\right)$, BOD, TSS, TDS, dan Phospat. Parameter kualitas air ini digunakan untuk mendapatkan informasi dasar tentang kondisi lingkungan perairan yang mendukung kelayakan budidaya ikan. Selain itu kondisi kualitas air yang didapatkan akan menjadi alat dalam memprediksi kondisi logam berat pada kolong tempat budidaya ikan. Data parameter kualitas air yang didapatkan selanjutnya dikorelasikan dengan persyaratan kehidupan ikan-ikan budidaya.

\section{Metode Penelitian}

Metode penelitian ini yaitu metode survey. Survey kolong yang akan dijadikan objek penelitian dilakukan secara purposive sampling. Pertimbangan digunakan metode ini yaitu sampel kolong yang digunakan haruslah sampel kolong yang terdapat kegiatan budidaya ikan oleh masyarakat. Selanjutnya untuk analisis data yang didapatkan yaitu data logam berat pada media air dan parameter kualitas air lainnya dilakukan dengan menggunakan metode indeks pencemaran Sumitomo dan Nemerow (1970) dalam Keputusan Menteri Lingkungan Hidup Nomor 115 tahun 2003. Metode ini mengusulkan suatu indeks berkaitan dengan senyawa pencemar yang memiliki makna untuk suatu peruntukan. Indeks ini dinyatakan sebagai Indeks Pencemaran (Pollution Index) yang digunakan untuk menentukan tingkat pencemaran relatif terhadap parameter kualitas air yang diizinkan. Metoda ini dapat langsung menghubungkan tingkat ketercemaran dengan dapat atau tidaknya 
perairan dipakai untuk penggunaan tertentu. Formula yang digunakan dalam metode ini yaitu :

$P l j=f\left(C_{i} / L_{i j}, C_{2} / L_{2 j}, \ldots . . C_{i} / L_{i j}\right)$

$\mathrm{Pl}_{\mathrm{j}}=$ Indeks pencemaran bagi peruntukan yang merupakan fungsi dari $\mathrm{C}_{\mathrm{i}} / \mathrm{L}_{\mathrm{ij}}$

$C=$ Konsentrasi parameter kualitas air (i) yang diperoleh dari hasil analisa sampel air pada suatu lokasi pengambilan sampel dari suatu alur perairan.

$\mathrm{L}_{\mathrm{ij}}=$ Konsentrasi parameter kualitas air yang dicantumkan dalam baku peruntukan air.

Parameter indeks pencemaran yang digunakan untuk menilai tercemarnya suatu perairan yaitu : $0<\mathrm{Pl}_{\mathrm{j}}<1,0=$ Memenuhi baku mutu (kondisi baik)
$1,0<\mathrm{Pl}_{\mathrm{j}}<5,0=$ cemar ringan

$5,0<\mathrm{PI}_{\mathrm{j}}<10=$ cemar sedang

$\mathrm{Pl}_{\mathrm{j}}>10=$ cemar berat

\section{Hasil dan Pembahasan}

\section{Kondisi dan Karakteristik Kolong}

Kolong yang digunakan untuk kegiatan budidaya ikan oleh para pembudidaya memiliki keadaan dan karakteristik yang beragam. Hasil survey yang dilakukan menunjukan kegiatan budidaya ikan dengan memanfaatkan kolong sebagai media budidaya dilakukan dengan sistem water base aquaculture. Kondisi ini terlihat pada Tabel 1.

Tabel 1. Kondisi dan Karakteristik Kolong Yang Digunakan Untuk Kegiatan Budidaya Ikan

\begin{tabular}{|c|c|c|c|}
\hline No. & Kolong & Karakteristik Fisik Kolong & $\begin{array}{c}\text { Keterangan Lokasi } \\
\text { dan Kepemilikan }\end{array}$ \\
\hline 1. & $\begin{array}{l}\text { Kolong Kampung Jeruk } \\
\text { (KJH) }\end{array}$ & $\begin{array}{ll}\text { - } & \text { Kolong Menengah terbentuk tahun } \\
& 2001 \text { (13 tahun) } \\
\text { - } & \text { Mulai kegiatan Budidaya tahun } 2013 \text { (1 } \\
\text { tahun) } \\
\text { - } \text { Banyak terdapat tanaman kayambang } \\
\text { pada permukaan kolong } \\
\text { - } \text { Kegiatan pendederan lele dumbo } \\
\text { - } \text { Menggunakan wadah Budidaya } \\
\text { keramba jaring tancap } \\
\text { - Kedalaman kolong } 50 \mathrm{~cm} \mathrm{-10} \mathrm{m}\end{array}$ & $\begin{array}{l}\text { Kampung Jeruk, } \\
\text { Kec.Pangkalan Baru, } \\
\text { Bangka Tengah, } \\
\text { Kelompok } \\
\text { Pembudidaya Ikan } \\
\text { (Pokdakan )Tiga Raja } \\
\text { yang melakukan } \\
\text { kegiatan Budidaya } \\
\text { Ikan }\end{array}$ \\
\hline 2. & Kolong Pedindang (KPI) & 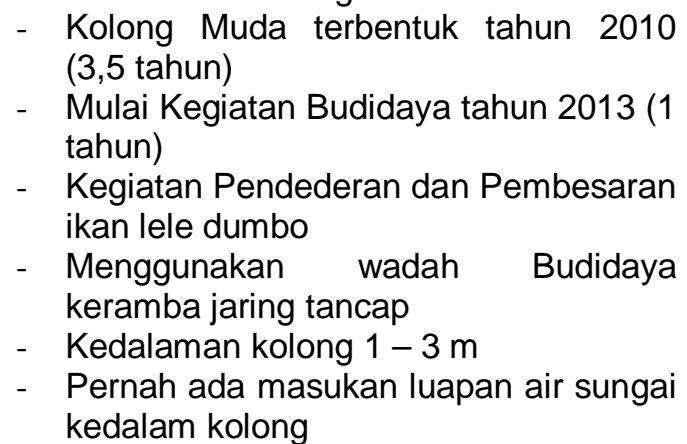 & $\begin{array}{l}\text { Desa Pedindang, } \\
\text { Kec.Pangkalang Baru, } \\
\text { Kab. Bangka Tengah, } \\
\text { Kelompok } \\
\text { Pembudidaya Ikan } \\
\text { (Pokdakan) Karya } \\
\text { Mandiri yang } \\
\text { melakukan kegiatan } \\
\text { Budidaya Ikan }\end{array}$ \\
\hline 3. & Kolong Pemali 1 (KWD) & $\begin{array}{l}\text { Kolong Menengah terbentuk tahun } \\
2008 \text { (6 tahun) } \\
\text { - } \quad \text { Mulai Kegiatan Budidaya tahun } 2010 \text { (4 } \\
\text { tahun) } \\
\text { - } \quad \text { Kegiatan Pendederan dan Pembesaran } \\
\text { ikan lele dumbo, Mas dan Nila } \\
\text { - } \quad \text { Menggunakan wadah } \\
\text { keramba jaring tancap } \\
\text { - } \text { Kedalaman kolong } 50 \mathrm{~cm} \mathrm{-} 7 \mathrm{~m} \\
\text { - } \quad \text { Ada aliran air kolong masuk dari kolong } \\
\text { yang lain. }\end{array}$ & $\begin{array}{l}\text { Pemali, Kab. Bangka, } \\
\text { Kelompok } \\
\text { Pembudidaya Ikan } \\
\text { (Pokdakan) Kube } \\
\text { Mentawai yang } \\
\text { melakukan kegiatan } \\
\text { Budidaya Ikan }\end{array}$ \\
\hline 4. & Kolong Pemali 2 (KAS) & $\begin{array}{l}\text { - Kolong Tua terbentuk tahun } 1984 \text { (30 } \\
\text { tahun) } \\
\text { - } \text { Kondisi kolong sudah terlihat sangat } \\
\text { mapan } \\
\text { - } \quad \text { Mulai Kegiatan Budidaya tahun } 2010 \text { (4 } \\
\text { tahun) } \\
\text { - } \text { Kegiatan Pendederan ikan lele dumbo } \\
\text { - } \\
\text { Menggunakan wadah Budidaya } \\
\text { keramba jaring tancap }\end{array}$ & $\begin{array}{l}\text { Pemali, Kab. Bangka, } \\
\text { Individu Pembudidaya } \\
\text { lkan yang melakukan } \\
\text { kegiatan Budidaya } \\
\text { lkan }\end{array}$ \\
\hline
\end{tabular}


- Kedalaman kolong $30 \mathrm{~cm}-3 \mathrm{~m}$

- Ada influent air dari kolong lain yang sudah tua dan effluent.

5. Kolong Pemali $3(\mathrm{KON})$ - Kolong Menengah terbentuk tahun Kolong Menengah terbentuk tahun Pemali, Kab. Bangka, 2004 (10 tahun)

- Mulai Kegiatan Budidaya tahun 2012 (2 tahun)

- Kegiatan Pendederan dan Pembesaran Pembudidaya Ikan yang melakukan kegiatan Budidaya Ikan Gurami

- Menggunakan wadah Budidaya keramba jaring tancap

Kedalaman kolong $50 \mathrm{~cm}-5 \mathrm{~m}$

Berdasarkan Tabel 1. diketahui bahwa usia kolong muda, menengah dan tua dapat digunakan untuk kegiatan budidaya ikan. Hal ini dikarenakan kondisi kualitas air pada kolong tersebut sudah mampu menunjang kelangsungan hidup ikan-ikan budidaya. Pada kolong-kolong muda dan menengah, kualitas air mampu memenuhi persyaratan ikan hidup dikarenakan kedalaman dari kolong-kolong tersebut tidak terlalu dalam sehingga menyebabkan kualitas air cepat pulih dan memenuhi persyaratan hidup ikan. Selain itu asupan air dari mata air, air hujan dan aliran air dari luar badan air juga ikut mendukung terciptanya perbaikan kualitas air untuk budidaya ikan yang lebih cepat. Ada diantara kolong-kolong tersebut ternyata memiliki aliran air masuk (influent) dan aliran air keluar (effluent) dari kolong lain yang usia kolongnya sama yaitu Kolong Pemali 1 dan 2. Semua kegiatan budidaya ikan di kolong-kolong tersebut dilakukan dengan menggunakan wadah berupa keramba jaring tancap. Penggunaan keramba jaring tancap sebagai wadah karena mudah dibuat pada kondisi kolong yang tidak terlalu dalam, lebih praktis dan mendukung kegiatan budidaya khususnya pendederan dan pembesaran pada skala yang besar.

\section{Kualitas Air Kolong}

Kualitas air kolong yang didapatkan secara umum cukup bervariasi. Beberapa kualitas air ada yang langsung diukur di lokasi kolong (insitu) sebagian yang lain diambil sampelnya dan diukur di laboratorium. Data pengukuran kualitas air disajikan pada Tabel 2.

Tabel 2. Nilai Parameter Kualitas Air Kolong Hasil Pengukuran

\begin{tabular}{lccccccc}
\hline $\begin{array}{l}\text { Parameter } \\
\text { Kualitas Air }\end{array}$ & Satuan & $\begin{array}{c}\text { Kolong } \\
\text { Kampung } \\
\text { Jeruk }\end{array}$ & $\begin{array}{c}\text { Kolong } \\
\text { Pedindang }\end{array}$ & $\begin{array}{c}\text { Kolong } \\
\text { Pemali 1 }\end{array}$ & $\begin{array}{c}\text { Kolong } \\
\text { Pemali 2 }\end{array}$ & $\begin{array}{c}\text { Kolong } \\
\text { Pemali 3 }\end{array}$ & $\begin{array}{c}\text { Baku } \\
\text { Mutu* }^{*}\end{array}$ \\
\hline DO & $\mathrm{mg} / \mathrm{l}$ & 3,34 & 4,67 & 4,47 & 5,09 & 3,46 & 3 \\
BOD & $\mathrm{mg} / \mathrm{l}$ & 0,74 & 3,428 & 3,006 & 3,75 & 1,64 & 6 \\
Kekeruhan & $\mathrm{NTU}$ & 6,97 & 12,584 & 67,54 & 20,9 & 73,18 & - \\
TSS & $\mathrm{mg} / \mathrm{l}$ & 32 & 128 & 166,4 & 108,33 & 108,4 & 400 \\
TDS & $\mathrm{mg} / \mathrm{l}$ & 8 & 19,6 & 22,8 & 2 & 19 & 1000 \\
Phospat & $\mathrm{mg} / \mathrm{l}$ & 0,147 & 0,329 & 0,869 & 0,396 & 0,7 & 1 \\
Nitrat & $\mathrm{mg} / \mathrm{l}$ & 3,378 & 4,988 & 8,998 & 3,024 & 8,381 & 20 \\
$\mathrm{pH}$ & - & 5,76 & 6,62 & 6,36 & 6,86 & 6,1 & $6-9$ \\
$\mathrm{~Pb}$ & $\mathrm{mg} / \mathrm{l}$ & $<0,03$ & $<0,03$ & $<0,03$ & $<0,03$ & $<0,03$ & 0,03 \\
$\mathrm{Zn}$ & $\mathrm{mg} / \mathrm{l}$ & 0,05 & 0,034 & 0,043 & 0,033 & 0,071 & 0,05 \\
$\mathrm{Cu}$ & $\mathrm{mg} / \mathrm{l}$ & $<0,015$ & $<0,015$ & $<0,015$ & $<0,015$ & $<0,015$ & 0,02 \\
\hline
\end{tabular}

Keterangan : * = Baku mutu bagi peruntukan kegiatan perikanan (kelas 3) berdasarkan PP No.82 tahun 2001

Berdasarkan nilai parameter kualitas air yang diukur didapatkan bahwa hampir semua kolong memenuhi kriteria baku mutu kualitas air bagi kegiatan perikanan kecuali pada kolong Pemali 3 yang kandungan logam berat $\mathrm{Zn}$ melebihi ambang batas baku mutu kualitas air. Selain itu kandungan logam berat $\mathrm{Pb}$ dan $\mathrm{Cu}$ berada dibawah ambang batas baku mutu. Rendahnya logam berat $\mathrm{Pb}$ dan tembaga $\mathrm{Cu}$ ini diduga karena batuan yang terkikis selama proses penambangan sedikit mengandung logam timbal dan tembaga sehingga saat terbentuk kolong keberadaan logam-logam tersebut sedikit. Parameter kualitas air lainnya cukup baik pada kolong-kolong yang berusia tua, muda dan menengah disebabkan perairan kolong tersebut mampu melakukan suksesi secara alami dan pulih diri (self purification).

Berdasarkan Tabel 2., nilai DO pada setiap kolong berada pada rentang 3-5 ppm. Rentang nilai tersebut masih memenuhi kisaran kebutuhan oksigen bagi biota-biota akuatik. Nilai 
DO pada Kolong Kampung Jeruk paling rendah dibandingkan yang lain karena kolong tumbuhan air jenis kayambang (Silvinia molesta) menutupi sebagian besar permukaan kolong. Banyaknya tumbuhan ini akan menghambat terjadinya difusi oksigen dari udara kedalam air. Nilai BOD pada setiap kolong terlihat cukup rendah. Rendahnya BOD dikarenakan bahan organik disetiap kolong tidak terlalu tinggi. BOD pada kolong kampung jeruk paling rendah karena lebih sedikitnya beban bahan organik masuk ke kolong yang terlihat dari lebih sedikitnya jumlah Keramba Jaring Tancap pada kolong tersebut.

Tingkat kekeruhan pada kolong rendah baik pada kolong tua, menengah dan muda pada Tabel 2. Beban bahan organik tanah dari kegiatan penambangan cepat mengendap ke dasar perairan karena dipengaruhi kedalaman kolong yang tidak terlalu dalam. Konsentrasi TSS dan TDS pada semua kolong juga terlihat masih cukup baik. Hal ini dikarenakan rendahnya kandungan bahan organik pada tiap-tiap kolong. Partikel-partikel tanah sebagian besar sudah mengendap didasar perairan. Selain itu beban limbah dari kegiatan budidaya ikan seperti : limbah organik sisa pakan dan feses, Phospat dan Nitrat yang seharusnya bisa mempengaruhi kualitas air tidak secara signifikan berpengaruh. Hal ini karena kegiatan budidaya ikan yang dilakukan oleh pembudidaya ikan belum terlalu lama dan bukan sistem budidaya intensif. Faktor pengendapan pada dasar perairan yang tidak terlalu dalam juga berpengaruh.

Nilai parameter kualitas air kolong berdasarkan Tabel 2. bervariasi antar kolong. Variasi nilai ini terjadi karena kondisi lingkungan tiap-tiap kolong berbeda. Selain itu pemeliharaan ikan-ikan budidaya yang secara kuantitas dan perlakuan saling berbeda antar kolong menyebabkan kondisi kualitas air juga ikut berbeda. Secara umum kondisi kualitas air pada semua kolong masih mendukung kelangsungan hidup dan pertumbuhan bagi ikan-ikan budidaya.

\section{Status Mutu Air Kolong}

Penentuan status mutu air kolong dilakukan dengan memasukan nilai parameter kualitas air yang diukur kedalam penghitungan metode indeks pencemaran. Berdasarkan perhitungan indeks pencemaran (IP) terlihat bahwa usia kolong tidak terlalu berpengaruh terhadap status mutu kualitas air kolong. Hal ini tersaji pada Tabel 3-7.

Tabel 3. Rekapitulasi Nilai Pij Penentuan Status Mutu Air Dengan Menggunakan Metode Indeks Pencemaran Pada Kolong Kampung Jeruk

\begin{tabular}{|c|c|c|c|c|c|}
\hline Parameter & Satuan & $\mathbf{C i}$ & Lix & Ci/Lix & Ci/Lix baru \\
\hline DO & $\mathrm{mg} / \mathrm{l}$ & 3,34 & 3 & 1,11 & 0,31 \\
\hline BOD & $\mathrm{mg} / \mathrm{l}$ & 0,74 & 6 & 0,12 & 0,12 \\
\hline TSS & $\mathrm{mg} / \mathrm{l}$ & 32 & 400 & 0,08 & 0,08 \\
\hline TDS & $\mathrm{mg} / \mathrm{l}$ & 8 & 1000 & 0,01 & 0,01 \\
\hline Phospat & $\mathrm{mg} / \mathrm{l}$ & 0,147 & 1 & 0,15 & 0,15 \\
\hline Nitrat & $\mathrm{mg} / \mathrm{l}$ & 3,378 & 20 & 0,17 & 0,17 \\
\hline $\mathrm{pH}$ & - & 5,76 & $6-9$ & 1,16 & 1,16 \\
\hline \multirow[t]{4}{*}{$\mathrm{Zn}$} & $\mathrm{mg} / \mathrm{l}$ & 0,05 & 0,05 & 1,00 & 1,00 \\
\hline & & & & (Ci/Lix)R & 0,37 \\
\hline & & & & (Ci/Lix)M & 1,16 \\
\hline & & & & $\mathrm{Pij}$ & 0,86 \\
\hline
\end{tabular}

Keterangan : $\mathrm{Ci}=$ Nilai parameter kualitas air yang terukur $; \mathrm{Lix}=$ Nilai baku mut kualitas air; $(\mathrm{Ci} / \mathrm{Lix}) \mathrm{R}=$ Nilai rata-rata $\mathrm{Ci} /$ Lix baru ; $(\mathrm{Ci} / \mathrm{Lix}) \mathrm{M}=$ Nilai maksimum Ci/Lix baru $; \mathrm{Pij}=$ Indeks pencemaran bagi peruntukan perikanan

Tabel 4. Rekapitulasi Nilai Pij Penentuan Status Mutu Air Dengan Menggunakan Metode Indeks Pencemaran Pada Kolong Pedindang

\begin{tabular}{|c|c|c|c|c|c|}
\hline Parameter & Satuan & $\mathbf{C i}$ & Lix & $\mathrm{Ci} / \mathrm{Lix}$ & Ci/Lix baru \\
\hline $\mathrm{DO}$ & $\mathrm{mg} / \mathrm{l}$ & 4,67 & 3 & 1,56 & 0,20 \\
\hline BOD & $\mathrm{mg} / \mathrm{l}$ & 3,428 & 6 & 0,57 & 0,57 \\
\hline TSS & $\mathrm{mg} / \mathrm{l}$ & 128 & 400 & 0,32 & 0,32 \\
\hline TDS & $\mathrm{mg} / \mathrm{l}$ & 19,6 & 1000 & 0,02 & 0,02 \\
\hline Phospat & $\mathrm{mg} / \mathrm{l}$ & 0,329 & 1 & 0,33 & 0,33 \\
\hline Nitrat & $\mathrm{mg} / \mathrm{l}$ & 4,988 & 20 & 0,25 & 0,25 \\
\hline $\mathrm{pH}$ & - & 6,62 & $6-9$ & 0,59 & 0,59 \\
\hline \multirow[t]{2}{*}{$\mathrm{Zn}$} & $\mathrm{mg} / \mathrm{l}$ & 0,034 & 0,05 & 0,68 & 0,68 \\
\hline & & & & $(\mathrm{Ci} / \mathrm{Lix}) \mathrm{R}$ & 0,37 \\
\hline
\end{tabular}




$\begin{array}{rr}(\mathrm{Ci} / \mathrm{Lix}) \mathrm{M} & 0,68 \\ \mathrm{Pij} & 0,55\end{array}$

Keterangan : $\mathrm{Ci}=$ Nilai parameter kualitas air yang terukur ; Lix = Nilai baku mutu kualitas air; (Ci/Lix)R = Nilai rata-rata $\mathrm{Ci} /$ Lix baru ; $(\mathrm{Ci} / \mathrm{Lix}) \mathrm{M}=$ Nilai maksimum $\mathrm{Ci} /$ Lix baru $; \mathrm{Pij}=$ Indeks pencemaran bagi peruntukan perikanan

Tabel 5. Rekapitulasi Nilai Pij Penentuan Status Mutu Air dengan Menggunakan Metode Indeks Pencemaran Pada Kolong Pemali 1

\begin{tabular}{|c|c|c|c|c|c|}
\hline Parameter & Satuan & $\mathbf{C i}$ & Lix & Ci/Lix & Ci/Lix baru \\
\hline DO & $\mathrm{mg} / \mathrm{l}$ & 4,47 & 3 & 1,49 & 0,23 \\
\hline BOD & $\mathrm{mg} / \mathrm{l}$ & 3,006 & 6 & 0,50 & 0,50 \\
\hline TSS & $\mathrm{mg} / \mathrm{l}$ & 166,4 & 400 & 0,42 & 0,42 \\
\hline TDS & $\mathrm{mg} / \mathrm{l}$ & 22,8 & 1000 & 0,02 & 0,02 \\
\hline Phospat & $\mathrm{mg} / \mathrm{l}$ & 0,869 & 1 & 0,87 & 0,87 \\
\hline Nitrat & $\mathrm{mg} / \mathrm{l}$ & 8,998 & 20 & 0,45 & 0,45 \\
\hline $\mathrm{pH}$ & - & 6,36 & $6-9$ & 0,36 & 0,36 \\
\hline \multirow[t]{4}{*}{$\mathrm{Zn}$} & $\mathrm{mg} / \mathrm{l}$ & 0,043 & 0,05 & 0,86 & 0,86 \\
\hline & & & & $(\mathrm{Ci} / \mathrm{Lix}) \mathrm{R}$ & 0,46 \\
\hline & & & & (Ci/Lix)M & 0,87 \\
\hline & & & & $\mathrm{Pij}$ & 0,70 \\
\hline
\end{tabular}

Keterangan : $\mathrm{Ci}=$ Nilai parameter kualitas air yang terukur ; Lix = Nilai baku mutu kualitas air; $(\mathrm{Ci} / \mathrm{Lix}) \mathrm{R}=\mathrm{Nilai}$ rata-rata $\mathrm{Ci} /$ Lix baru ; $(\mathrm{Ci} /$ Lix $) \mathrm{M}=$ Nilai maksimum $\mathrm{Ci} /$ Lix baru $; \mathrm{Pij}=$ Indeks pencemaran bagi peruntukan perikanan

Tabel 6. Rekapitulasi Nilai Pij Penentuan Status Mutu Air Dengan Menggunakan Metode Indeks Pencemaran Pada Kolong Pemali 2

\begin{tabular}{|c|c|c|c|c|c|}
\hline Parameter & Satuan & $\mathbf{C i}$ & Lix & Ci/Lix & Ci/Lix baru \\
\hline DO & $\mathrm{mg} / \mathrm{l}$ & 5,09 & 3 & 1,70 & 0,17 \\
\hline BOD & $\mathrm{mg} / \mathrm{l}$ & 3,75 & 6 & 0,63 & 0,63 \\
\hline TSS & mg/l & 108,33 & 400 & 0,27 & 0,27 \\
\hline TDS & $\mathrm{mg} / \mathrm{l}$ & 2 & 1000 & 0,002 & 0,002 \\
\hline Phospat & mg/l & 0,396 & 1 & 0,40 & 0,40 \\
\hline Nitrat & $\mathrm{mg} / \mathrm{l}$ & 3,024 & 20 & 0,15 & 0,15 \\
\hline $\mathrm{pH}$ & - & 6,86 & $6-9$ & 0,43 & 0,43 \\
\hline \multirow[t]{4}{*}{$\mathrm{Zn}$} & $\mathrm{mg} / \mathrm{l}$ & 0,033 & 0,05 & 0,66 & 0,66 \\
\hline & & & & $(\mathrm{Ci} / \mathrm{Lix}) \mathrm{R}$ & 0,34 \\
\hline & & & & (Ci/Lix)M & 0,66 \\
\hline & & & & $\mathrm{Pij}$ & 0,52 \\
\hline
\end{tabular}

Keterangan : $\mathrm{Ci}=$ Nilai parameter kualitas air yang terukur ; Lix = Nilai baku mutu kualitas air ; $(\mathrm{Ci} / \mathrm{Lix}) \mathrm{R}=\mathrm{Nilai}$ rata-rata $\mathrm{Ci} /$ Lix baru ; $(\mathrm{Ci} / \mathrm{Lix}) \mathrm{M}=$ Nilai maksimum $\mathrm{Ci} /$ Lix baru $; \mathrm{Pij}=$ Indeks pencemaran bagi peruntukan perikanan

Tabel 7. Rekapitulasi Nilai Pij Penentuan Status Mutu Air Dengan Menggunakan Metode Indeks Pencemaran Pada Kolong Pemali 3

\begin{tabular}{|c|c|c|c|c|c|}
\hline Parameter & Satuan & $\mathbf{C i}$ & Lix & Ci/Lix & $\mathrm{Ci} /$ Lix baru \\
\hline DO & $\mathrm{mg} / \mathrm{l}$ & 3,46 & 3 & 1,15 & 0,29 \\
\hline BOD & $\mathrm{mg} / \mathrm{l}$ & 1,64 & 6 & 0,27 & 0,27 \\
\hline TSS & $\mathrm{mg} / \mathrm{l}$ & 108,4 & 400 & 0,27 & 0,27 \\
\hline TDS & $\mathrm{mg} / \mathrm{l}$ & 19 & 1000 & 0,02 & 0,02 \\
\hline Phospat & $\mathrm{mg} / \mathrm{l}$ & 0,7 & 1 & 0,70 & 0,70 \\
\hline Nitrat & $\mathrm{mg} / \mathrm{l}$ & 8,381 & 20 & 0,42 & 0,42 \\
\hline $\mathrm{Ph}$ & - & 6,1 & 6-9 & 0,10 & 0,10 \\
\hline \multirow[t]{4}{*}{$\mathrm{Zn}$} & $\mathrm{mg} / \mathrm{l}$ & 0,071 & 0,05 & 1,42 & 1,76 \\
\hline & & & & $(\mathrm{Ci} / \mathrm{Lix}) \mathrm{R}$ & 0,48 \\
\hline & & & & $(\mathrm{Ci} / \mathrm{Lix}) \mathrm{M}$ & 1,76 \\
\hline & & & & $\mathrm{Pij}$ & 1,29 \\
\hline
\end{tabular}

Keterangan : $\mathrm{Ci}=$ Nilai parameter kualitas air yang terukur $; \mathrm{Lix}=$ Nilai baku mutu kualitas air ; $(\mathrm{Ci} / \mathrm{Lix}) \mathrm{R}=\mathrm{Nilai}$ rata-rata $\mathrm{Ci} / \mathrm{Lix}$ baru ; $(\mathrm{Ci} / \mathrm{Lix}) \mathrm{M}=$ Nilai maksimum $\mathrm{Ci} / \mathrm{Lix}$ baru $; \mathrm{Pij}=$ Indeks pencemaran bagi peruntukan perikanan 
Hasil analisis status mutu air kolong dengan menggunakan perhitungan IP menunjukan bahwa kolong kampung jeruk, kolong pedindang, kolong pemali 1 dan kolong pemali 2 nilai indeks pencemaran berada dibawah 1. Hal ini menunjukan bahwa kolong-kolong tersebut memenuhi baku mutu untuk kegiatan budidaya ikan. IP kolong pemali 3 sebesar 1,29 yang berarti bahwa kondisi kolong tersebut tercemar ringan. Kategori Kolong Pemali 3 masuk kategori cemar ringan dikarenakan salahsatu parameter kualitas air berupa seng ( $\mathrm{Zn})$ berada diatas ambang batas baku mutu kualitas air. Tingginya ambang batas tersebut dikarenakan logam berat seng pada kolong pemali 3 cukup banyak dan belum mengendap didasar perairan.

Berdasarkan data-data yang didapatkan ternyata usia kolong tidak berpengaruh terhadap tingkat kecemaran kualitas air pada kolongkolong tersebut. Status mutu air kolong berdasarkan metode IP menunjukan bahwa walaupun kolong berusia muda atau menengah namun memenuhi kriteria baku mutu. Hal ini mengindikasikan bahwa usia kolong tidak begitu mempengaruhi tingkat kecemaran kolong.

\section{Kandungan Logam Berat Ikan Hasil Budidaya}

Kandungan logam berat dapat terakumulasi pada daging ikan jika media air mengandung logam berat. Logam berat yang terkandung pada daging ikan-ikan yang dibudidayakan di kolong-kolong terlihat pada Tabel 8.

Tabel 8. Kandungan Logam Berat Pada Daging Ikan Yang Dibudidayakan Pada Kolong

\begin{tabular}{|c|c|c|c|}
\hline \multirow{2}{*}{ Kolong } & \multicolumn{3}{|c|}{$\begin{array}{c}\text { Kandungan Logam Berat Pada } \\
\text { Daging Ikan }\end{array}$} \\
\hline & $\begin{array}{c}\mathrm{Pb} \\
(\mathrm{mg} / \mathrm{Kg})\end{array}$ & $\begin{array}{c}\mathrm{Zn} \\
(\mathrm{mg} / \mathrm{Kg})\end{array}$ & $\begin{array}{c}\mathrm{Cu} \\
(\mathrm{mg} / \mathrm{Kg})\end{array}$ \\
\hline Kolong Kampung Jeruk (KJH) & $<0,030$ & 0,008 & $<0,015$ \\
\hline Kolong Pedindang (KPI) & $<0,030$ & 0,008 & $<0,015$ \\
\hline Kolong Pemali 1 (KWD) & $<0,030$ & 0,006 & $<0,015$ \\
\hline Kolong Pemali 2 (KAS) & $<0,030$ & 0,005 & $<0,015$ \\
\hline Kolong Pemali 3 (KON) & $<0,030$ & 0,01 & $<0,015$ \\
\hline
\end{tabular}

Berdasarkan hasil yang didapatkan, kandungan logam berat daging ikan pada semua kolong masih berada dibawah ambang batas yang dipersyaratkan. Rendahnya kandungan logam berat ini dikarenakan media air kolong kandungan logam beratnya juga rendah. Kandungan logam berat pada sedimen diduga tidak terlalu tinggi sehingga peluang lepasnya logam berat dari sedimen ke kolom air atau terjadinya proses biomagnifikasi tidak terjadi.

\section{PEMBAHASAN}

Kolong-kolong dimanfaatkan oleh para pembudidaya ikan bervariasi dari segi usia dan karakteristik. Berdasarkan aliran airnya terdapat dua jenis kolong yaitu kolong yang memliki aliran air masuk (influent) dan keluar (effluent) serta kolong yang tidak memiliki aliran air masuk dan keluar. Kolong pada saat awal terbentuk kondisi kualitas airnya sangat buruk. Seiring dengan usia kolong yang bertambah, kolong akan mengalami perbaikan kualitas secara alami (pulih diri). Hal ini akan semakin cepat jika terjadi proses pengenceran (dillution) oleh asupan air dari luar yang masuk kedalam kolong dan kedalaman kolong yang rendah. Asupan air dari luar dapat berasal dari air tanah (mata air), hujan atau badan air lain. Kolong-kolong pada penelitian ini sebagian ada yang memiliki asupan air dari luar kolong dan optimal digunakan untuk kegiatan budidaya ikan. Kolong-kolong berusia muda dan menengah pada penelitian ini memiliki kualitas air yang sudah baik dikarenakan adanya asupan air dari luar kolong dan diduga karena faktor kedalaman dan volume total yang relatif lebih rendah dari kolong yang dalam sehingga flushing air dalam sistem kolong menjadi lebih cepat. Kolong dengan kedalaman dibawah 10 meter bisa lebih cepat pulih diri (self purification) karena pengendapan bahan organik tanah berupa TDS dan TSS berlangsung lebih cepat. Bahan organik tanah ini dapat berikatan dengan ion-ion positif dan logam yang menyebabkan kandungan logam berat konsentrasinya menjadi rendah di kolom perairan. Selain itu kolong dengan kedalaman yang rendah diduga asam-asam humus yang menyebabkan $\mathrm{pH}$ rendah jumlahnya lebih sedikit terangkat pada saat kegiatan penambangan ke air kolong sehingga nilai $\mathrm{pH}$ tidak rendah. Pada kondisi $\mathrm{pH}$ yang lebih tinggi $(\mathrm{pH}>5)$ kelarutan logam berat di air rendah dan logam berat cenderung mengendap. DO relatif cukup baik untuk kehidupan biota akuatik pada kolong disebabkan karena proses difusi oksigen ke perairan berlangsung dengan baik dan proses fotosintesis oleh tumbuhan air dan fitoplankton berlangsung secara optimal. DO yang sudah baik mendukung proses perombakan bahan-bahan 
organik oleh mikroorganisme aerob didalam air. Hal ini terlihat dari besarnya kebutuhan oksigen untuk merombak senyawa organik (BOD) pada kolong yang nilainya cukup rendah. Rendahnya nilai $B O D$ selain kandungan $D O$ yang optimal juga dipengaruhi oleh kandungan bahan organik pada perairan kolong yang rendah. Kandungan bahan organik terutama bahan organik dari dekomposisi tumbuhan atau hewan yang mati bisa menyebabkan kandungan nitrat dan phospat pada perairan tinggi. Namun pada penelitian ini kandungan nitrat dan phospat rendah dikarenakan ketercemaran bahan organik pada perairan juga rendah. Secara umum berdasarkan data-data kualitas air kolong hasil penelitian didapatkan bahwa kondisi ekologi kolong sudah baik dan layak. Terbentuknya kolong pada saat awal kondisi ekologi dan kualitas perairannya rusak namun seiring dengan bertambahnya usia kolong akan mengalami perbaikan secara alami (Puspita et al 2005). Kualitas air kolong secara alami akan pulih membutuhkan waktu puluhan tahun namun kualitas air akan terjadi lebih cepat bila kolong berhubungan dengan perairan dari luar kolong (Prasetiyono 2014). Suksesi kolong juga akan lebih singkat bila ada asupan air dari luar kolong dan adanya kegiatan reklamasi kolong (Henny dan Susanti 2009).

Kandungan logam berat yang terdapat pada media air kolong, seperti : $\mathrm{Pb}, \mathrm{Zn}$ dan $\mathrm{Cu}$ berasal dari perut bumi yang muncul ke media air kolong diakibatkan oleh proses kegiatan penambangan. Seiring dengan mengendapnya bahan-bahan organik tanah ke dasar perairan dan $\mathrm{pH}$ perairan yang semakin meningkat, maka kandungan logam berat dapat mengendap atau terikat pada bahan organik tanah yang mengendap ke dasar perairan tersebut. Rendahnya kandungan logam berat $\mathrm{Pb}, \mathrm{Zn}$ dan $\mathrm{Cu}$ pada penelitian ini bisa disebabkan karena mengendapnya logam berat tersebut ke perairan sehingga kandungan di kolom air yang terukur rendah. Selain itu rendahnya kandungan logam berat $\mathrm{Pb}, \mathrm{Zn}$ dan $\mathrm{Cu}$ pada kolong juga bisa disebabkan karena tipe mineral yang terkandung pada kolong tersebut sedikit mengandung logam berat $\mathrm{Pb}, \mathrm{Zn}$ dan $\mathrm{Cu}$. Logam berat memiliki sifat mudah mengikat bahan organik dan mengendap serta berikatan dengan partikel-partikel sedimen. Hal ini menyebabkan konsentrasi logam berat dalam sedimen lebih tinggi dibanding dalam air (Hidayat 2011). Logam berat yang terlarut dalam air akan berpindah ke dalam sedimen jika berikatan dengan materi organik bebas atau materi organik yang melapisi permukaan sedimen atau penyerapan langsung oleh permukaan partikel sedimen. Tingginya kandungan logam berat tertentu pada suatu kolong sangat tergantung pada tipe mineral di area kolong dan $\mathrm{pH}$ air kolong. Air yang pHnya masih rendah dapat terus melarutkan logam yang ada di sedimen ataupun pada area kolong. Sebagian besar logam berat seperti : $\mathrm{Fe}, \mathrm{Pb}, \mathrm{Zn}$,
Al dan $\mathrm{Cu}$ mudah terlarut dan sangat mudah bergerak pada $\mathrm{pH}>5$ (Henny 2010).

Kandungan logam berat dapat terakumulasi didalam tubuh biota akuatik. Berdasarkan penelitian ini kandungan logam berat pada tubuh ikan yang dibudidayakan oleh pembudidaya ikan sangat rendah dan berada dibawah ambang batas. Hal ini dikarenakan rendahnya kandungan logam berat di air yang masuk kedalam tubuh ikan melalui media air (biokonsentrasi) dan proses biomagnifikasi yang kemungkinan tidak terjadi. Walaupun pemeliharaan ikan dilakukan di kolong muda maupun menengah namun kandungan logam berat di tubuh ikan rendah dan aman dikonsumsi manusia. Kondisi ini membuktikan bahwa usia kolong tidak berkorelasi dengan kandungan logam berat yang dapat masuk kedalam tubuh ikan. Secara umum proses masuknya logam berat kedalam tubuh ikan melalui beberapa cara yaitu biokonsentrasi, biomagnifikasi dan bioakumulasi. Biokonsentrasi yaitu masuknya kandungan logam berat kedalam tubuh ikan melalui media air baik secara osmoregulasi maupun difusi permukaan (pori-pori) kulit tubuh ikan. Biomagnikasi yaitu kandungan logam berat masuk kedalam tubuh ikan melalui rantai makanan sedangkan bioakumulasi yaitu masuknya logam berat kedalam tubuh ikan secara biokonsentrasi dan biomagifikasi. Logam berat mampu berikatan dengan senyawasenyawa lain, seperti nitrat $\left(\mathrm{NO}_{3}\right)$. Senyawa nitrat merupakan sumber nutrisi atau makanan bagi fitoplankton. Fitoplankton kemudian dimakan oleh zooplankton atau langsung dimakan oleh ikanikan herbivor dan selanjutnya dikonsumsi oleh ikan carnivora sehingga menyebabkan ikan terakumulasi logam berat. Prinsip logam berat masuk ke tubuh ikan secara osmoregulasi didasarkan pada aktivitas hewan akuatik yang selalu melakukan osmoregulasi dalam upaya mengkontrol keseimbangan air dan ion antara tubuh dan lingkungannya. Proses masuknya air dan ion-ion kedalam tubuh ikan dengan cara meminum air atau langsung melalui insang menyebabkan logam berat intrusi kedalam tubuh ikan. Selain itu logam berat juga dapat masuk melalui absorpsi permukaan kulit ikan terjadi secara pasif baik secara difusi maupun osmosis (Prasetiyono, 2014).

\section{KESIMPULAN}

Kolong-kolong yang digunakan oleh masyarakat untuk kegiatan budidaya ikan sebagian besar memenuhi kelayakan untuk kegiatan perikanan. Usia kolong tidak berpengaruh terhadap ketercemaran kualitas air kolong. Hal ini dikarenakan kolong-kolong tersebut kedalamannya rendah (dibawah 10 meter) dan ada asupan air dari luar kedalam kolong. Selain itu kegiatan budidaya ikan yang bisa menyumbang pasokan limbah kedalam 
kolong tidak berpengaruh signifikan karena kegiatan budidaya yang dilakukan belum terlalu lama dan masih memenuhi kapasitas perairan kolong.

\section{DAFTAR PUSTAKA}

Gautama RS. 2014. Pengendalian dan Pengolahan Air Limbah Tambang. Pusat Studi Lingkungan Hidup Institut Teknologi Bandung. $1-51$.

Henny C, Susanti E. 2009. Karakteristik limnologis kolong bekas tambang timah di Pulau Bangka. Limnotek 26: 119-131.

Henny C. 2010. "Kolong" Bekas Tambang Timah di Pulau Bangka: Permasalahan Kualitas air dan Alternatif Solusi Untuk pemanfaatan. Oseanologi dan Limnologi Indonesia 37(1): 119 - 138.

Hidayat D. 2011. Kajian Sebaran Logam Berat $\mathrm{Pb}$ Pada Sedimen Di Muara Sungai Way Kuala Bandar Lampung. Jurnal Sains MIPA17 (3): 115 - 119.

Kordi MGHK, Tancung AB. 2007. Pengelolaan Kualitas Air Dalam Budidaya Perairan. Jakarta : Rinneka Cipta.

Prasetiyono, E. 2013. Efektivitas Kompos Batang Pisang (Musa sp.) Untuk meminimalisasi kandungan logam berat timah hitam $(\mathrm{Pb})$ dan menaikan $\mathrm{pH}$ rendah pada media budidaya ikan lele dumbo (Clarias gariepinus). Akuatik-Jurnal sumberdaya Perairan 7 (1) : 1-8.

Prasetiyono E. 2014. Akuakultur Berbasis Kolong Pasca Tambang Timah : Prinsip Pemanfaatan dan Kelayakan Budidaya Ikan. Buletin Fordas Babel 2 (1) : 14-18.

Pujiastuti P, Ismail B, Pranoto. 2013. Kualitas Dan Beban Pencemaran Perairan Waduk Gajah Mungkur. Jurnal EKOSAINS 5 (1). $59-75$.

Puspita L, Ratnawati E, Suryadiputra INN, Meutia AA. 2005. Lahan Basah Buatan di Indonesia. Bogor : Wetlands International Indonesia Programme.

Sumitomo dan Nemerow, 1970 dalam Kepmen KLH 115, Th 2003. Pedoman Penentuan Status Mutu Air, Kementrian Lingkungan Hidup. 2004

Wardoyo SE, Ismail W. 1998. Aspek Fisika, Kimia, dan Biologi Kolong-Kolong di Pulau Bangka Untuk Pengembangan Perikanan. Jurnal Penelitian Perikanan Indonesia 4(2). 